\title{
Different fattening systems of lberian pig according to 1-alkene hydrocarbon content in the subcutaneous fat
}

\author{
By I. Viera-Alcaide ${ }^{1}$, M. Narváez-Rivas ${ }^{1}$, I.M. Vicarioº ${ }^{2}$, E. Graciani-Constante ${ }^{1}$, \\ and M. León-Camacho ${ }^{1, *}$
}
1 Instituto de la Grasa (C.S.I.C.), Food Characterization and Quality Department. Seville, Spain.
${ }^{2}$ Department of Nutrition and Food Science. Faculty of Pharmacy. University of Seville. Spain.
* Corresponding author: e-mail: mleon@ cica.es

\section{RESUMEN}

Diferentes sistemas de cebado del cerdo lbérico según el contenido de 1-alqueno en la grasa subcutánea.

El contenido de n-alquenos de la grasa subcutánea de 755 muestras procedentes de cerdos ibéricos machos, se ha determinado mediante combinación off-line de los métodos HPLC y GC. Las muestras correspondían a tres grupos según el tipo de alimentación en el período final de engorde ("Montanera", alimentados con bellota y pasto; "Recebo", alimentados con bellota, pasto y pienso; y "Cebo", alimentados con pienso y pasto). Usando los $\mathrm{n}$-alquenos como descriptores químicos, se aplicaron técnicas de análisis multivariante para diferenciar entre los tres tipos de alimentación de cerdo ibérico. Se encontró que las variables más diferenciadores fueron $n-C_{16: 1}, n-C_{18: 1}, n-C_{22: 1}$ y $n-C_{24: 1}$. Sin embargo, el total de las muestras no están clasificadas, mejorando el nivel de clasificación cuando se eliminan las muestras correspondientes a animales de "Recebo". Para el "Cebo", se encontró una relación entre los niveles de $n-C_{14: 1}, n-C_{16: 1}$ y $n-C_{18: 1}$ y el período de sacrificio, siendo los niveles de estos muy bajos cuando los animales, no eran de cría en extensivo y no tenían pasto en su dieta de engorde.

PALABRAS CLAVE: Cerdo ibérico - Cromatografía gaseosa - Grasa subcutánea - 1-alquenos - Sistemas de engorde.

\section{SUMMARY}

Different fattening systems of lberian pigs according to the 1-alkene hydrocarbon content in the subcutaneous fat.

The n-Alkene content in samples of subcutaneous fat corresponding to 755 castrated male Iberian pigs has been determined by an off-line combination of HPLC and GC method. The samples corresponded to three groups based on the type of feeding during the finish fattening period ("Montanera", fed on acorns and pasture; "Recebo", fed on acorns, feed and pasture; and "Cebo", fed on feed and pasture). By using the n-alkenes as chemical descriptors, multivariate statistical techniques were applied to differentiate between the three fattening diet types for Iberian pigs. The most differentiating variables were $n-C_{16.1}, n-C_{18.1}$, $\mathrm{n}-\mathrm{C}_{22: 1}$ and $\mathrm{n}-\mathrm{C}_{24: 1}$. However, a clear classification of the samples was not achieved. The level of classification was improved when the data corresponding to the animals fed with the "Recebo" fattening diet was removed from the analysis. A relationship between $n-C_{14: 1}, n-C_{16: 1}$ and $n-C_{18: 1}$ levels and the slaughter period was found to be very low for the animals fed with the "Cebo" fattening diet when the animals had not been closely managed and pasture had not been included in their fattening diet.

KEY-WORDS: Fattening systems - Gas chromatography - Iberian pig - 1-alkenes - Subcutaneous fat.

\section{INTRODUCTION}

Nowadays consumers demand high quality products with particular sensory or health properties. The products made from Iberian pig meat comply with these requirements since they have a much appreciated organoleptic taste and they can be considered healthy from their fat composition point of view (high in oleic acid) García Rebollo et al. (1998). The Iberian pig (Sus Mediterraneus) production systems is one of the few traditional ones (together with certified Parma ham production) which has survived due to the highly demanded characteristics of the derived drycured products, with a lasting taste and rich nutty flavor (Andersen et al., 2005; Bosi et al., 2000). Besides, the outdoor rearing in the Mediterranean silvopastoral system (called "La Dehesa"), has a positive image for consumers since it is associated with an increase in animal welfare, reduced environmental impact and protection of a traditional production system (López Bote, 1998; Rey et al., 2006; Bénédicte and Guillard, 2005). The animals are reared outdoors, grazing on acorns (Quercus spp) and pasture, in what is usually called "Montanera". The key problem of this system is that the availability of resources in "La Dehesa" is limited and sometimes it is necessary to complete feeding during the final fattening period with formulated feeds which are usually called "Recebo". On other farms, the animals are fed formulated feed during the final fattening period in order to reach the adequate slaughter weight; this system is called "Cebo". Classification of the animals into one of these groups has an economic and industrial effect, since the best quality, highly priced dry-cured hams are related to "Montanera" animals followed by "Recebo" and "Cebo". At the moment, the fatty acid analysis of the subcutaneous fat by gas chromatography (GC) is 
an unsatisfactory criterion for classifying the animals according to the three feeding system (B.O.E., 2007). Other analytical parameters are being explored as alternatives to fatty acids to establish the feeding system of the animals previous to slaughter. In this sense triacylglycerol analysis has been proposed as an alternative to fatty acids (Viera-Alcaide et al., 2007; Viera-Alcaide et al., 2008) which improves classification results. The hydrocarbon fraction has also been explored. Hydrocarbons are components of vegetable waxes which have been used for authentication purposes (León-Camacho and Morales, 2000). Their presence in animal' tissue has been related to the diet consumed by the animals during the fattening period (Bandurski and Nagi, 1975). The traditional feeding of Iberian pigs is based on acorns and pasture. In the hydrocarbon profile of acorns medium chain-alkanes $\left(\mathrm{C}_{29}\right.$ and $\left.\mathrm{C}_{27}\right)$ predominate and comprise about $80 \%$ of total hydrocarbons detected, while other n-alkanes account for less than 10\% (León-Camacho et al. 2004)). In the fresh fat of Iberian pigs (Tejeda et al., 1999; Tejeda et al., 2001a; Tejeda et al., 2001b; Gamero-Pasadas et al., 2006) and in intramuscular fat of dry-cured hams (Petrón et al., 2004; Petrón et al., 2005; Petrón et al., 2006), several authors have described the linear saturated hydrocarbons, from $n-C_{14}$ up to $\mathrm{n}-\mathrm{C}_{29}$ except $\mathrm{n}-\mathrm{C}_{23}$ and $\mathrm{n}-\mathrm{C}_{28}$ n-alkanes, n-alkenes from $n-C_{12}$ to $n-C_{32}$, and branched hydrocarbons. Short chain hydrocarbons under $n-C_{12}$ have not yet been identified. In relation to branch hydrocarbons, some of them remain unidentified, probably due to analytical problems. To improve the isolation of the unsaponifiable fraction of lipids, thin layer chromatography (TLC) Petrón et al. (2006) and liquid chromatography (LC) Tejeda et al. (2001b) are being replaced by HPLC methods (LeónCamacho and Morales, 2000). Recently a new HPLC-GC off line method that allows isolation and quantification of the hydrocarbon fraction was reported by Gamero-Pasadas et al. (2006) who also described a new diterpenic hydrocarbon, entKaurene, for the first time in the subcutaneous fresh fat of the Iberian pig.

Although some authors have reported that the differences in linear hydrocarbons are insufficient at the moment to discriminate hams from Iberian pigs fattened on different diets, they have reported dietrelated differences in some branched hydrocarbons Petrón et al. (2006).
The aim of this work was to study the n-alkene hydrocarbon profile of the subcutanous fat of Iberian pigs reared extensively on the three types of fattening diets: "Montanera" $(M)$, "Cebo" $(C)$ and "Recebo" $(R)$. The effect of the rearing system on the hydrocarbon composition was also studied. The final objective was to explore the feasibility of using the n-alkene hydrocarbon profile for classification purposes of samples corresponding to different fattening diets.

\section{MATERIALS AND METHODS}

\subsection{Animals and samples}

The samples analyzed in this study were representative of 50640 castrated male Iberian pigs reared extensively under the guidelines of the Designation of Origin "Jamón de Huelva". Data were collected during three consecutives campaigns (2002 to 2005). One group of animals (23966 animals) was fed on acorns and pasture, this system is usually called "Montanera". Other group (13925 animals) was fed with feed and pasture, usually called "Cebo" and the last group (12749 animals) was fed with acorns, feed and pasture, usually called "Recebo". Animals were assigned to the different groups according to the field notes taken by the veterinary inspector of the Designation of Origin.

\section{Samples}

A total of 755 samples of Iberian pig fat were analyzed (Table 1). Raw samples were obtained by the official method (BOE, 2004) and the representative sample of the lot was obtained as described elsewhere Viera-Alcaide et al. (2008). The unsaponifiable fraction was extracted following the procedure described in Gamero-Pasadas et al. (2006). Briefly, $1 \mathrm{~mL}$ of the Standard solution of $\mathrm{n}$ eicosane was added to $20 \mathrm{~g}$ of fat. The mixture was saponified for one hour with $75 \mathrm{~mL}$ of $10 \%$ ethanolic potassium hydroxide. The solution was transferred to a $500-\mathrm{mL}$ decanting funnel, $100 \mathrm{~mL}$ distilled water were added and the mixture was extracted twice with tree $100-\mathrm{mL}$ portions of hexane. The hexane extracts were combined in another funnel and were washed several times with 100-mL portions of a mixture of ethanol-water (1:1), until the wash was at a neutral $\mathrm{pH}$. The hexane solution was dried over anhydrous sodium sulphate and

Table 1

Total animals and samples analyzed from different campaigns

\begin{tabular}{ccccccc}
\hline \multirow{2}{*}{ Campaign } & \multicolumn{2}{c}{ “Montanera” } & \multicolumn{2}{c}{ “Recebo" } & \multicolumn{2}{c}{ "Cebo" } \\
\cline { 2 - 7 } & samples & animals & Samples & animals & Samples & animals \\
\hline $\mathbf{2 0 0 2 - 2 0 0 3}$ & 174 & 10572 & 71 & 5087 & 89 & 6171 \\
\hline $\mathbf{2 0 0 3 - 2 0 0 4}$ & 119 & 7740 & 61 & 3515 & 48 & 3646 \\
\hline $\mathbf{2 0 0 4 - 2 0 0 5}$ & 83 & 5654 & 45 & 4147 & 65 & 4108 \\
\hline
\end{tabular}


evaporated to dryness in a rotary evaporator at $30^{\circ} \mathrm{C}$ under reduced pressure.

\subsection{HPLC separation}

The HPLC system consisted of an Agilent (Palo Alto, CA, USA) 1100 liquid chromatograph, with a quaternary pump, a Rheodyne (Cotati, CA, USA) injection valve (300 $\mu \mathrm{L}$ loop), a Peltier furnace and a refractive index detector. A Valco Instruments $\mathrm{Co}$. Inc. (Bandera, TX, USA) valve model VT-E90 was installed at the output of the detector for the recovery of the hydrocarbon fraction. A Chemical station HP was used for controlling and monitoring the system. The separation was performed in a 250 $\times 4 \mathrm{~mm}$ particle size $5 \mu \mathrm{m}$ Lichrospher Si 60 Merck (Darmstadt, Germany) column. The temperature of the column and the detector were held, respectively, at 30 and $35^{\circ} \mathrm{C}$. The mobile phase was n-hexane/ethyl acetate 85/15 (v/v). The flow rate was supported at $1 \mathrm{~mL} \mathrm{~min}{ }^{-1}$ for $30 \mathrm{~min}$.

The complete unsaponifiable fraction was dissolved in approximately $300 \mu \mathrm{L}$ of mobile phase, and the solution was injected into the HPLC system. The fraction that eluted from minute 1.0 to 4.50 was recovered through the VALCO valve and concentrated in the rotary evaporator at $30^{\circ} \mathrm{C}$ under reduced pressure to $0.15 \mathrm{~mL}$ and analyzed by gas chromatography.

\subsection{GC Analysis}

The hydrocarbon fraction was analyzed as described elsewhere Gamero-Pasadas et al. (2006). A VARIAN (Palo Alto, CA, USA) 3800 gas chromatograph equipped with a split/splitless injector and a flame ionization detector; a Capillary column (30 $\mathrm{m} \times 0,22 \mathrm{~mm}$ i.d.) coated with a 0,12 $\mu \mathrm{m}$ film of a Teknokroma TRB-ESTEROL stationary phase and a VARIAN 8100 automatic injector were used. The temperature program was as follows: initial temperature at $114^{\circ} \mathrm{C}, 4^{\circ} \mathrm{C} \mathrm{min}{ }^{-1}$ to $310^{\circ} \mathrm{C}$, followed by an isothermal period of $11 \mathrm{~min}$ at the latter temperature. The injector and detector were held at 280 and $320^{\circ} \mathrm{C}$ respectively. Hydrogen was used as carrier gas at a constant head pressure of $10 \mathrm{psi}$, and a split ratio of 1:40 was used. Air and hydrogen with flow rates of 300 and $30 \mathrm{~mL} \mathrm{~min}^{-1}$, respectively, were used for the detector, which had an auxiliary flow of $30 \mathrm{~mL} \mathrm{~min}^{-1}$ of nitrogen. Table 2 shows the 1alkenes of the subcutaneous fat of the Iberian pigs used in this study and their retention times.

Each component in the chromatogram was quantified using n-eicosane as internal standard. The response factor relative to n-alkanes and nalkenes was close the unit.

\subsection{Statistical analysis}

For classification purposes, ANOVA-MANOVA, Principal Component (PCA) and Linear Discriminant Analysis (LDA) were applied to the hydrocarbon composition to infer differences between groups according to the fattening diet. The Bonferroni test was applied for Post-hoc comparisons. For LDA the criterion used for the feature selection of variables included in the model was the forward stepwise approach. The variables were included in the model according to their discriminating power based on the Wilks' $\lambda$ statistic test (StatSoft, 2002). The multivariate statistical analysis was performed using the software Statistica ${ }^{\circledR} \vee 6.0$ (Statsoft Inc., 2001)

\section{RESULTS AND DISCUSSION}

\section{1. n-Alquene profile of adipose tissue}

The contents of single $n$-alkene determined (mean and standard deviation) are shown in Table 2 , together with the corresponding retention times. Twenty-one $n$-alquenes, including even (ECNE) and odd (OCNE) carbon number n-alquenes were identified in the samples subjected to the HPLC_GC method. The n-alkene profile was characterized by a predominance of ECNE (7.96 $\pm 4.10 \mathrm{mg} \cdot \mathrm{kg}^{-1}$ ) among which the main components were those from $\mathrm{C}_{14: 1}$ to $\mathrm{C}_{18: 1}\left(5.73 \pm 3.38 \mathrm{mg} \cdot \mathrm{kg}^{-1}\right)$, in accordance with previously published data for the intramuscular fat of lberian dry-cured ham (Petrón et al., 2004). On the contrary, odd carbon number alquenes (OCNE) were found at low levels $\left(0.73 \pm 0.28 \mathrm{mg} \cdot \mathrm{kg}^{-1}\right.$ ). Up to now, OCNE (from $\mathrm{C}_{13: 1}$ to $C_{31: 1}$ ) and the very short chain hydrocarbon $C_{12: 1}$ had not been described in the subcutaneous fat of Iberian pigs, probably due to the low levels in which they are found (below $0.20 \mathrm{mg} \cdot \mathrm{kg}^{-1}$ )

It has been reported that the feeding system has no significant effect on the hydrocarbon profile of Iberian ham intramuscular lipid Petrón et al. (2004). However, we found significant differences in most of the $n$-alquenes analyzed when the three feeding systems were considered as separate groups (Table 2). In general, the mean values obtained for n-alquenes were higher for the animals fed on Montanera, followed by Recebo and, finally by Cebo animals. This is the case of ECNE, for which the animals fed on Montanera presented values significantly higher $(p<0.05)$ than Recebo and Cebo. The main ECNEs presented significant differences in relation to the fattening diet. $C_{14: 1}$ content was significantly $(p<0.05)$ higher for Montanera and Recebo pigs than for Cebo, while $\mathrm{C}_{16: 1}$ and $\mathrm{C}_{18: 1}$ presented significantly higher values for Montanera than for Recebo and Cebo. However, for OCNE, the highest values were found for the animals fed on Recebo followed by Cebo and Montanera. Similar results have been obtained by other authors for the intramuscular fat of dry-cured hams (Petrón et al., 2004; Petrón et al., 2005).

\subsection{Principal components analysis}

In order to view the grouping trend of the variables according to the type of fattening diet, an 
Table 2

Retention time $\left(R_{t}\right)$, mean (ppm) and standard Deviation (S.D.), of 1-alkenes fraction of Iberian pig subcutaneous fat

\begin{tabular}{|c|c|c|c|c|c|}
\hline n-alkenes & $\begin{array}{c}R_{t} \\
(\min )\end{array}$ & $\begin{array}{c}\text { All Groups } \\
n=717\end{array}$ & $\begin{array}{c}\text { Montanera } \\
n=365\end{array}$ & $\begin{array}{c}\text { Recebo } \\
\mathrm{n}=173\end{array}$ & $\begin{array}{l}\text { Cebo } \\
\mathrm{n}=179\end{array}$ \\
\hline$n-C_{12: 1}$ & 4.14 & $0.20 \pm 0.35^{\star \star}$ & $0.26 \pm 0.42^{\mathrm{a}}$ & $0.19 \pm 0.30^{a}$ & $0.09 \pm .12^{b}$ \\
\hline$n-C_{13: 1}$ & 5.55 & $0.01 \pm 0.01^{\star \star}$ & $0.00 \pm 0.01^{a}$ & $0.01 \pm 0.02^{b}$ & $0.01 \pm 0.02^{a}$ \\
\hline$n-C_{14: 1}$ & 7.49 & $1.66 \pm 1.23^{* \star}$ & $1.81 \pm 1.20^{\mathrm{a}}$ & $1.62 \pm 1.32^{\mathrm{a}}$ & $1.39 \pm 1.13^{b}$ \\
\hline$n-C_{15: 1}$ & 9.95 & $0.05 \pm 0.05^{* \star}$ & $0.04 \pm 0.02^{a}$ & $0.05 \pm 0.04^{b}$ & $0.08 \pm 0.08^{c}$ \\
\hline$n-C_{16: 1}$ & 12.29 & $2.29 \pm 1.46^{\star \star}$ & $2.52 \pm 1.47^{a}$ & $2.13 \pm 1.38^{b}$ & $1.99 \pm 1.45^{b}$ \\
\hline$n-C_{17: 1}$ & 15.12 & $0.07 \pm 0.09^{* \star}$ & $0.05 \pm 0.08^{a}$ & $0.09 \pm 0.09^{b}$ & $0.10 \pm 0.11^{b}$ \\
\hline$n-C_{18: 1}$ & 17.58 & $1.78 \pm 1.23^{\star *}$ & $1.96 \pm 1.28^{a}$ & $1.62 \pm 1.08^{b}$ & $1.57 \pm 1.20^{b}$ \\
\hline$n-C_{19: 1}$ & 20.35 & $0.05 \pm 0.05$ & $0.05 \pm .004$ & $0.06 \pm 0.06$ & $0.06 \pm 0.05$ \\
\hline$n-C_{20: 1}$ & 22.71 & $0.40 \pm 0.54^{\star \star}$ & $0.36 \pm 0.52^{a}$ & $0.57 \pm 0.67^{b}$ & $0.31 \pm 0.40^{a}$ \\
\hline$n-C_{21: 1}$ & 25.29 & $0.04 \pm 0.03$ & $0.04 \pm 0.03$ & $0.03 \pm 0.02$ & $0.04 \pm 0.02$ \\
\hline$n-C_{22: 1}$ & 27.49 & $0.72 \pm 0.51^{* *}$ & $0.81 \pm 0.52^{a}$ & $0.63 \pm 0.48^{b}$ & $0.64 \pm 0.49^{b}$ \\
\hline $\mathrm{n}-\mathrm{C}_{23: 1}$ & 29.88 & $0.05 \pm 0.04$ & $0.05 \pm 0.04$ & $0.05 \pm 0.03$ & $0.05 \pm 0.04$ \\
\hline $\mathrm{n}-\mathrm{C}_{24: 1}$ & 31.93 & $0.38 \pm 0.27$ & $0.41 \pm 0.28^{a}$ & $0.33 \pm 0.26^{b}$ & $0.36 \pm 0.26^{a}$ \\
\hline$n-C_{25: 1}$ & 34.13 & $0.09 \pm 0.05^{\star *}$ & $0.07 \pm 0.03^{a}$ & $0.11 \pm .06^{b}$ & $0.09 \pm 0.04^{c}$ \\
\hline$n-C_{26: 1}$ & 36.04 & $0.21 \pm 0.17^{*}$ & $0.23 \pm 0.18^{a}$ & $0.18 \pm 0.16^{b}$ & $0.21 \pm 0.15^{\mathrm{a}}$ \\
\hline$n-C_{27: 1}$ & 38.08 & $0.10 \pm 0.04^{* \star}$ & $0.10 \pm 0.03^{a}$ & $0.12 \pm .04^{b}$ & $0.09 \pm 0.03^{c}$ \\
\hline$n-C_{28: 1}$ & 39.89 & $0.18 \pm 0.19^{\star}$ & $0.16 \pm .018^{a}$ & $0.21 \pm 0.22^{b}$ & $0.19 \pm 0.17^{a}$ \\
\hline $\mathrm{n}-\mathrm{C}_{29: 1}$ & 41.75 & $0.16 \pm 0.06^{\star \star}$ & $0.17 \pm .006^{a}$ & $0.17 \pm 0.07^{a}$ & $0.12 \pm 0.03^{b}$ \\
\hline $\mathrm{n}-\mathrm{C}_{30: 1}$ & 43.43 & $0.13 \pm 0.13$ & $0.13 \pm .013$ & $0.14 \pm 0.14$ & $0.14 \pm 0.11$ \\
\hline $\mathrm{n}-\mathrm{C}_{31: 1}$ & 45.19 & $0.12 \pm 0.05$ & $0.11 \pm .005$ & $0.12 \pm 0.06$ & $0.12 \pm 0.05$ \\
\hline$\Sigma \mathbf{n}-\mathbf{C}_{\text {even }}$ & & $7.96 \pm 4.10^{\star \star}$ & $8.65 \pm 3.54^{a}$ & $7.63 \pm 4.73^{b}$ & $6.89 \pm 4.26^{c}$ \\
\hline$\Sigma \mathbf{n}-\mathbf{C}_{\text {odd }}$ & & $0.73 \pm 0.28^{\star \star}$ & $0.69 \pm 0.22^{a}$ & $0.81 \pm 0.35^{b}$ & $0.75 \pm 0.29^{a}$ \\
\hline $\begin{array}{l}\Sigma n-C_{14: 1} \\
C_{16: 1} C_{18: 1}\end{array}$ & & $5.73 \pm 3.38^{\star \star}$ & $6.29 \pm 2.94^{\mathrm{a}}$ & $5.37 \pm 3.69^{b}$ & $4.95 \pm 3.71^{c}$ \\
\hline
\end{tabular}

${ }^{* *} p<0.01 ;{ }^{*} p<0.05$; means within the same row which have a different superscript are significantly different $p<0.05$.

analysis of principal components was applied. A varimax rotation was done and 4 factors with weights higher than 1 were extracted. The total variance explained was $68.0 \%$ when the analyses included the 21 n-alkenes determined. When only OCNE were included the variance explained was higher (72.9\% of the total variance) and the highest was obtained by ECNA $(95.0 \%$ of the total variance). PC1 and PC2 explain up to $76.41 \%$ of the total variance, with $45.93 \%$ explained by $\mathrm{PC} 1$ and $30.48 \%$ by PC2. To visualize trends in the data, the scores for samples and loadings for variables were represented in the space of the two principal components (PCs) obtained by PCA Meloun et al. (1992). Figure 1A shows the loading of the variables in this space. As can be seen, the most contributing variable (avoiding correlation among them) are: $n-C_{24: 1}, n-C_{22: 1}$ (correlated with $n-C_{26: 1}$ ), n$\mathrm{C}_{18: 1}$ (correlated with $\mathrm{n}-\mathrm{C}_{28: 1}$ ) and $\mathrm{n}-\mathrm{C}_{16: 1}$ (correlated with $\left.n-C_{30: 1}\right)$. Accordingly, the scores plot obtained by selecting the variables most contributing to PC1 $\left(n-C_{16: 1}, n-C_{18: 1}, n-C_{22: 1}\right.$ and $\left.n-C_{24: 1}\right)$ is depicted in Figure 1B, and it can be observed that a good separation between groups was not achieved.

When the PCA was conducted in the same conditions described above but excluding the Recebo samples, the 4 factors extracted explained $100.0 \%$ of the total variance. The hydrocarbons which had a major positive contribution to the PC1 were the same as in the previous analysis. PC1 and PC2 explained up to $99.05 \%$ of the total variance, with $86.36 \%$ explained by PC1 and $12.69 \%$ by PC2, but the separation between groups was not improved. 

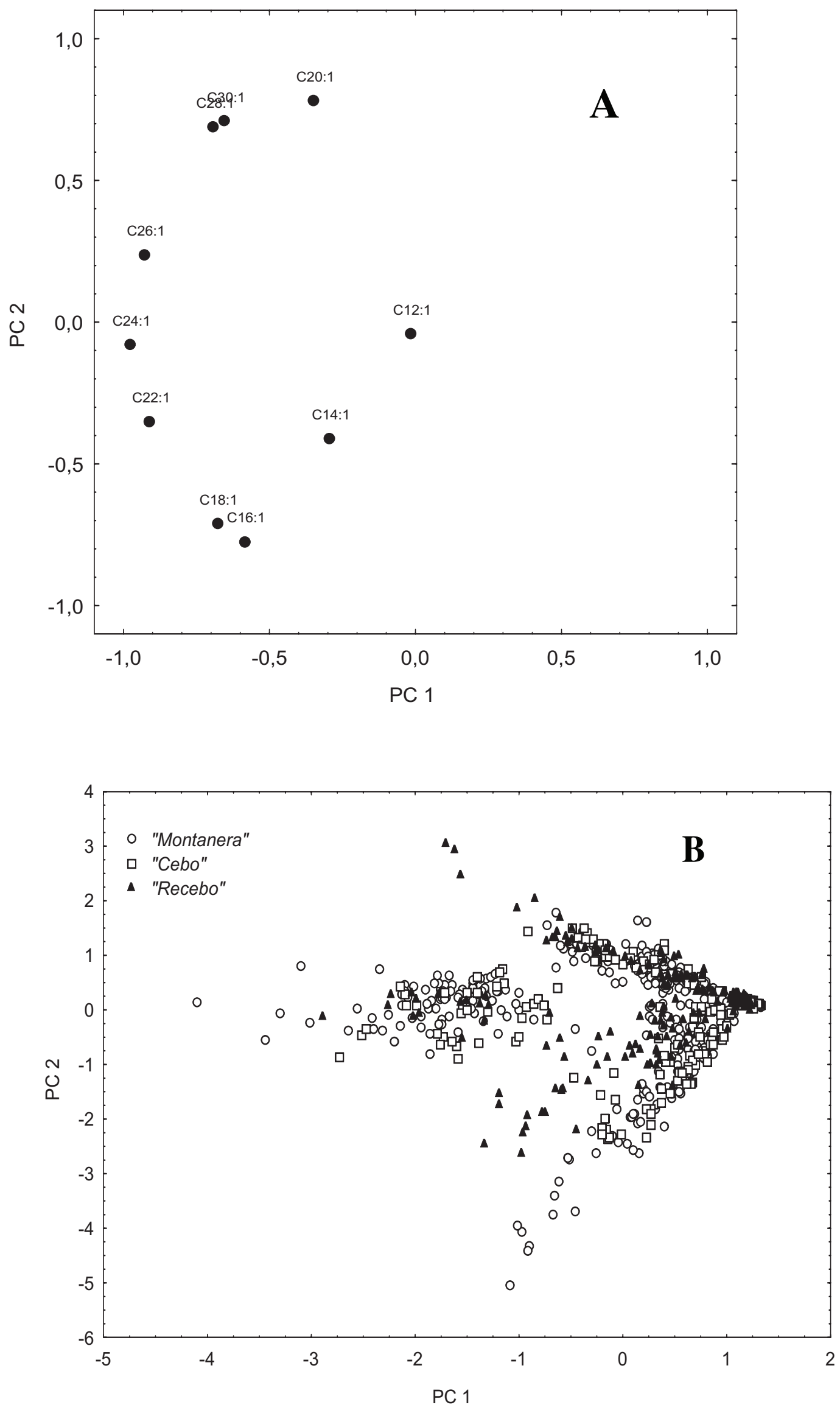

Figure 1

(A) Projection of the hydrocarbon variables and (B) the Montanera (M) and Cebo (C) and Recebo (R) samples onto the space define by PC1 and PC2. 


\subsection{Discriminant Analysis}

To achieve a better separation of the groups according to fattening diets a linear discriminant analysis (LDA) was carried out. The $21 \mathrm{n}$-alquenes were included as variables considering "a priori" equal probability for a sample to be in one group independently of the group size. A tolerance of 0.001 was set to eliminate the variables that provided redundant information with those already included in the model. The hydrocarbons included in the model were 17. The $\mathrm{C}_{15: 1}$ hydrocarbon with a higher $F$ value $(F=32.7)$ offered the best discrimination among the three groups. As can be observed in Table 3, the classification of the samples was not good, with a $73.64 \%$ of total results. The highest percentage predicted of correct classification was obtained for "Montanera" samples (81.09\%), while the "Recebo" and "Cebo" samples were misclassified. Figure $2 \mathrm{~A}$ shows the case discrimination, grouped by fattening diet, according to the first two canonical variables or square roots obtained from the classification functions.

In the same way that it was done with previous variables studied, an alternative classification was made considering only two distinct groups of fattening diet: "Cebo" and "Montanera". In this case, the hydrocarbons included in the model were 16. The $\mathrm{C}_{29: 1}$ hydrocarbon provided the best discrimination between the two groups. As can be observed in Table 4, the classification of the

Table 3

Classification matrix of the cases. Observed classifications in rows and predicted classifications in columns, for three fattening diet types

\begin{tabular}{ccccc}
\hline & $\begin{array}{c}\text { \% correct } \\
\text { classification }\end{array}$ & $\begin{array}{c}\mathbf{M} \\
\mathbf{M}\end{array} \mathbf{0 . 3 3 3 3 3}$ & $\boldsymbol{p}=\mathbf{0 . 3 3 3 3 3}$ & $\boldsymbol{p}=\mathbf{\mathbf { R }}$ \\
$\mathbf{M}$ & 81.33333 \\
\hline $\mathbf{C}$ & 76.53 & 296 & 28 & 41 \\
\hline $\mathbf{R}$ & 54.91 & 51 & 27 & 95 \\
\hline Total samples & 73.64 & 369 & 192 & 156 \\
\hline
\end{tabular}

Table 4

Classification matrix of the cases. Observed classifications in rows and predicted classifications in columns, for the two fattening diet types

\begin{tabular}{|c|c|c|c|}
\hline & $\begin{array}{c}\% \text { correct } \\
\text { classification }\end{array}$ & $\begin{array}{l}\text { "Montanera" } \\
p=0.50000\end{array}$ & $\begin{array}{c}\text { "Cebo" } \\
p=0.50000\end{array}$ \\
\hline M & 91.23 & 333 & 32 \\
\hline C & 84.92 & 27 & 152 \\
\hline Total samples & 89.15 & 360 & 184 \\
\hline
\end{tabular}

samples was better than in the previous case, in which the three fattening diets were taken into consideraton. A higher percentage of correct classifications was obtained.

Figure 2B shows the case discrimination, grouped by fattening diet, according to the first canonical variable or square roots obtained from the classification functions for the two types of fattening diets. In this figure, a significant overlap between the two groups can be observed.

\subsection{Influence of the rearing system on hydrocarbon levels}

The level of hydrocarbons present in the subcutaneous fat of the animals has been related to the fattening diet since these compounds are depositted in the animals' tissues without any modification (Bandurski and Nagi, 1975). Previous studies have addressed this point, discovering higher levels of some branch hydrocarbon in Iberian pig subcutaneous fat samples corresponding to animals fed extensively on Montanera for a long period of time (Tejeda et al., 2001; Petrón et al., 2006). This is an advisable result since pasture is the main source for these compounds and in extensive dietary systems the period that the animals remain eating pasture is variable depending on the available resources. In dry-cured meat, this relationship has also been reported for some branch hydrocarbons. We have explored the levels of hydrocarbons in relation to the season of the year when the animals were sacrificed (Figure 3). For "Cebo" animals, which are slaughtered throughout the year a decrease in the levels of the most important OCNA (sum of 1tetradecene, 1-hexadecene and 1-octadecene) can be observed during the dry seasons, when pasture is scarce or unavailable. This can be explained by the fact that "Cebo" animals have been reared outdoors. It can be observed that the hydrocarbon values do not exceed $2 \mathrm{mg} \mathrm{kg}^{-1}$ of fat during summer and early autumn, while higher values are obtained in winter and spring.

\section{CONCLUSIONS}

According to the results obtained in this study, the n-alkene profile of subcutaneous adipose tissue of the Iberian pig is affected by the fattening diet system.

However, n-alquene is not a good parameter to discriminate among animals fed extensively on $M$, $\mathrm{C}$ and $\mathrm{R}$. However for animals reared extensively on $C$ diets, a relationship between the OCNE $\left(n-C_{14: 1}\right.$, $n-C_{16: 1} y n-C_{18: 1}$ ) level and the season of the year when the animals are slaughtered has been found. The lowest levels $\left(<0.2 \mathrm{mg} \cdot \mathrm{kg}^{-1}\right)$ were found in animals reared intensively, when pasture was not included in their fattening diet. 

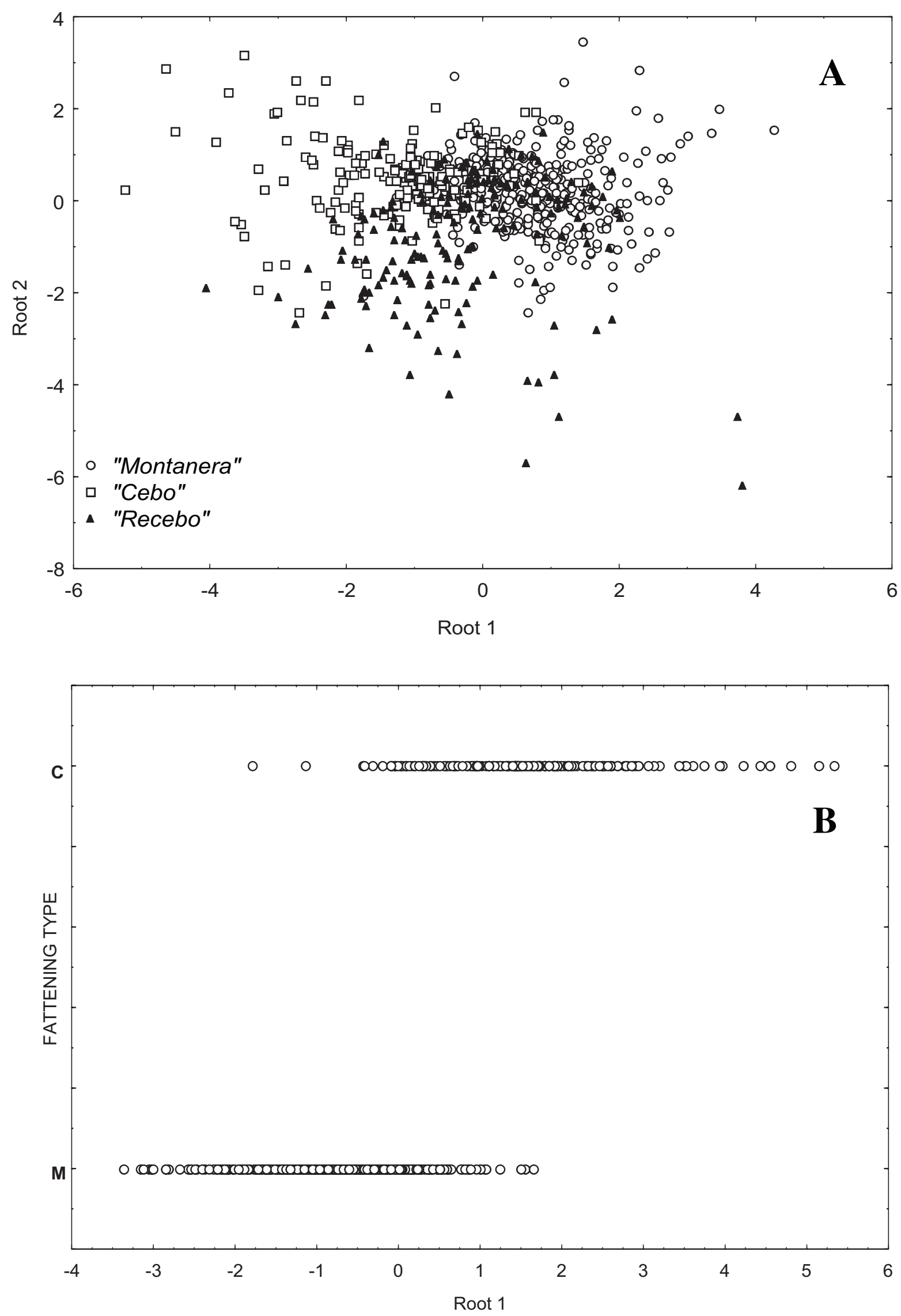

Figure 2

A: Scatterplot of the canonical scores corresponding to "Montanera", "Recebo" and "Cebo". B: Scatterplot of the canonical scores corresponding to "Montanera" and "Cebo". 


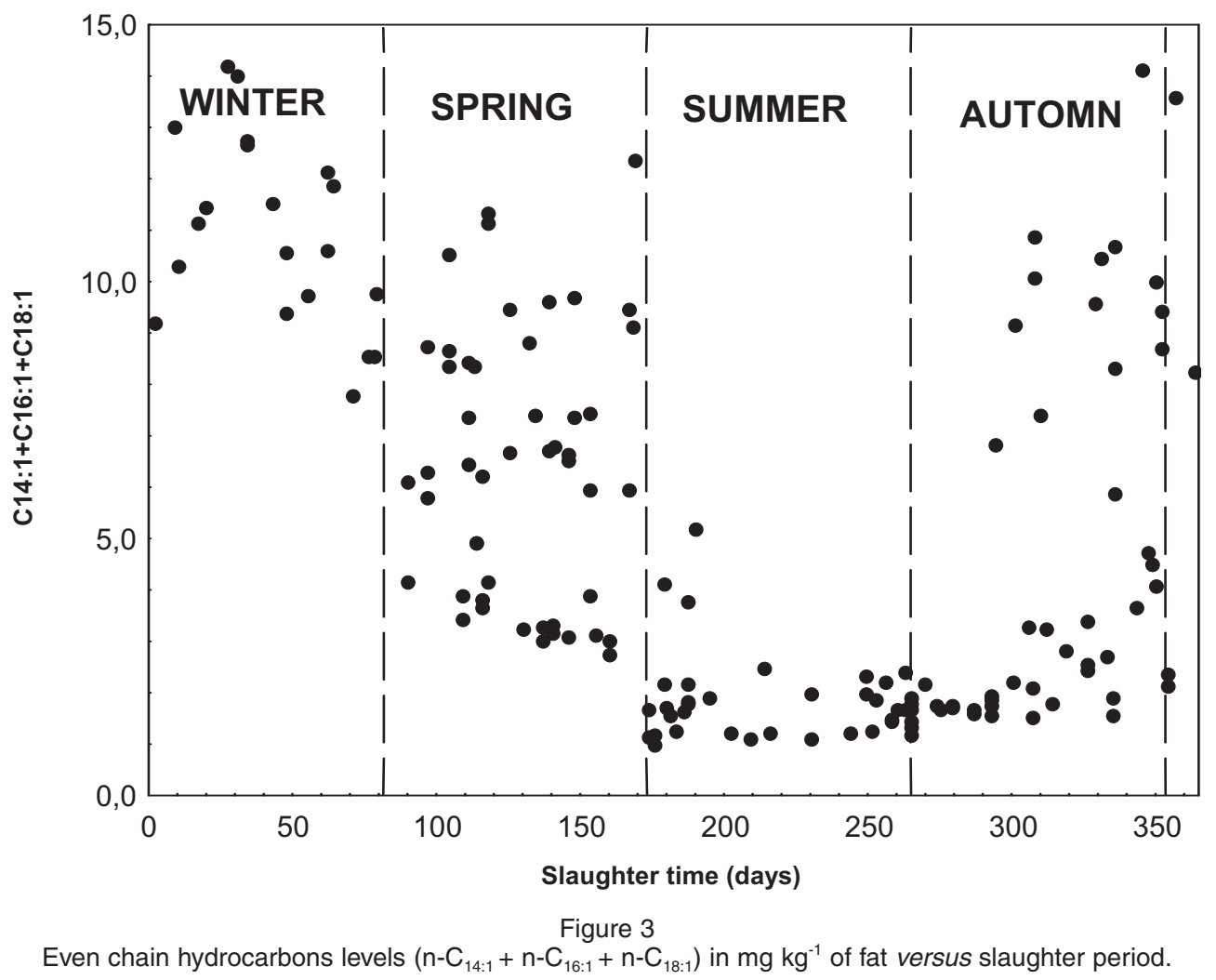

\section{ACKNOWLEDGEMENTS}

The authors are grateful to the Designation of Origin "Jamón de Huelva" especially to Mr. J. de Mier for the collaboration and given help and Ms. E. Oliveras for the technical assistance.

\section{REFERENCES}

Andersen HJ, Oksbjerg N, Young JF, Therkildsen $\mathrm{M}$. 2005. Feeding and meat quality- a future approach. Meat Sci. 70, 543-554.

Bandurski EL, Nagi, B. 1975. Nature of Alkanes in beef Heart Lipids. Lipids 10, 67-69.

Bénédicte L, Guillard A. 2005. Outdoor rearing of cull sows: Effects on carcass, tissue composition and meat quality. Meat Sci. 70, 247-257.

Boletín Oficial del Estado (BOE) 2004. Orden PRE/ 3844/2004. Por la que se establecen los métodos oficiales de toma de muestras en canales de cerdos ibéricos y el método de análisis para la determinación de la composición de ácidos grasos de los lípidos totales del tejido adiposo subcutáneo de cerdos ibéricos. (pp. 38770-38775). Madrid, Spain.

Boletín Oficial del Estado (BOE) 2007. REAL DECRETO 1469/2007. Por el que se aprueba la norma de calidad para la carne, el jamón, la paleta y la caña de lomo ibéricos. (pp. 45087-45104). Madrid, Spain.

Bosi P, Cacciavillani JA, Casini L, Lo Fiego DP, Marchetti M. 2000. Effects of dietary high-oleic acid sunflower oil, Koper and vitamin $E$ levels on the fatty acid composition and the quality of dry cured Parma ham. Meat Sci. 54, 119-126.
Gamero-Pasadas A, Viera Alcalde I, Rios JJ, Graciani Constante E, Vicario IM, León-Camacho M. 2006. Characterization and quantification of the hydrocarbons fraction of the subcutaneous fresh fat of Iberian pig by off line combination of high performance liquid chromatography and gas chromatography. J Chrom. A. 1123, 82-91.

García Rebollo AJ, Maciá Botejara E, Ortiz Cansado A, Morales PJ, Martín Bellido M, Fallola Sánchez A, Mena Arias P, Campillo Álvarez JE. 1998. Effects of consumption of meat product rich in monounsaturated fatty acids (the ham from the Iberian pig) on plasma lipids. Nutr Res. 18, 743-750.

León-Camacho M and Morales MT. 2000. Gas and Liquid Chromatography: Methodology Applied to Olive Oil, in Harwood JL and Aparicio R (Ed.). Handbook of Olive Oil: Analysis and Properties. Aspen, Gaithersburg, MD, 159-208.

León-Camacho M, Viera-Alcaide I, Vicario IM. 2004. Acorn (Quercus spp.) Fruit lipids: Saponificable and Unsaponificable fractions: a detail study. J Am Oil Chem Soc. 81, 447-453.

Lintas C, Balduzzi AM, Bernardini MP, Di Muccio A. 1979. Distribution of hydrocarbons in bovine tissues. Lipids 14, 298-303.

López Bote CJ. 1998. Sustained utilization of the Iberian pig breed. Meat Sci. 49,(suppl).S17-S27.

Martín Q. 2001. Curso de tratamiento de datos estadísticos con SPSS. Editorial Hespérides, Salamanca (Spain).

Meloun M, Militky J, Forina M. 1992. Chemometrics for Analytical Chemistry. Ellis Horwood, New York.

Petrón MJ, Antequera T, Muriel E, Tejeda JF, Ventanas J. 2004. Linear hydrocarbons content of intramuscular lipids of dry-cured Iberian ham. Meat Sci. 66, 295300. 
Petrón MJ, Muriel E, Tejeda JF, Ventanas J, Antequera T. 2006. Effect of duration of the Montanera diet on hydrocarbon fraction of intramuscular lipids from Iberian dry-cured ham; characterization by gas chromatography. J Sci Food Agric. 86, 1040-1045.

Petrón MJ, Tejeda JF, Muriel E, Ventanas J, Antequera T. 2005. Study of the branched hydrocarbon fraction of intramuscular lipids from Iberian dry-cured ham. Meat Scie. 69, 129-134.

Rey Al, Daza A, López-Carrasco C, López-Bote CJ. 2006. Feeding lberian pigs with acorns and grass in either free-range or confinement affects the carcass characteristics and fatty acids and tocopherols accumulation in Longissimus dorsi muscle and backfat. Meat Sci. 73 (1): 66-74.

StatSoft Inc. (1995). Statistica 5.5 for Windows Computer Program, Tulsa, OK. StatSoft, Inc., 1995, 2300 East 14th Street, Tulsa, OK 74104.

StatSoft Inc. (2001). Statistica for Windows v.6.0. Data analysis software system, Tulsa, Oklahoma.

StatSoft, Inc. (2002). Electronic Statistics Textbook. Tulsa OK: StatSoft. Available at: http://www.statsoft.com/ textbook/stathome.html.

Tejeda JF, Antequera T, Martín L, Ventanas J, García C. 2001a. Study of the branched hydrocarbon fraction of intramuscular lipids from Iberian fresh ham. Meat Sci. 58, 175-179.

Tejeda JF, Antequera T, Ruiz J, Cava R, Ventanas J, García C. 1999. Unsaponifiable fraction and n-alkane profile of subcutaneous fat from Iberian ham. Food Sci Technol Int. 5, 229-233.

Tejeda JF, García C, Petrón MJ, Andrés Al, Antequera T. 2001b. n-Alkane content of intramuscular lipids of Iberian fresh ham from different feeding systems and crossbreeding. Meat Sci. 57, 371-377.

Viera-Alcaidea, I, Vicario IM, ,Graciani Constante E, LeónCamacho, M. 2007. Authentication of fattening diet of Iberian pig according to Their triacylglycerol profile from subcutaneous fat. Anal. Chim. Acta 596, 319-324.

Viera-Alcaidea, I, Vicario IM, Escudero-Gilete, ML, Graciani Constante E, León-Camacho, M. 2008. A multivariate study of the triacylglycerols composition of the subcutaneous adipose tissue of iberian pig in relation to the fattening diet and genotype. Grasas y Aceites 59, 327-338. 